\title{
Application of Defatted Scenedesmus Obliquus Biomass for Broilers' Nutrition
}

http://dx.doi.org/10.1590/1806-9061-2020-1366

\section{-Author(s)}

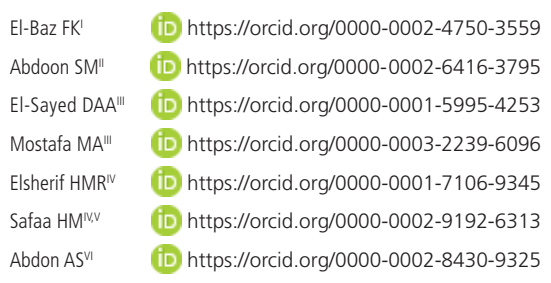

Plant Biochemistry Department, National Research Centre, Cairo, Egypt.

" Water Pollution Research Department, National Research Centre, Cairo, Egypt.

III Animal Production Research Institute, Agricultural Research Centre, Cairo, Egypt.

Iv Animal Production Department, Faculty of Agriculture, Cairo University, Giza 12613, Egypt. Department of Biology, College of Science, University of Bisha, Bisha 67722, Kingdom of Saudi Arabia.

Department of Animal Reproduction and Artificial Insemination, Veterinary Research Division, National Research Centre, Cairo, Egypt.

\section{Mail Address}

Corresponding author e-mail address Hosam M. Safaa

Production Departament of Agriculture, Cairo University, Egypt.

Phone: +201223475675

Email: hosam.safaa@agr.cu.edu.eg

\section{- Keywords}

Broilers' productivity; broilers' physiologica and immunological status; defatted green algae biomass.

\section{ABSTRACT}

A total of 480 Arbor Acres Broiler chicks (mixed sex) from 1 to 35 days of age were divided randomly into 4 treatments to evaluate the impact of defatted Scenedesmus obliquus biomass (DAB) on broiler performance. The DAB was supplemented to broiler diets with levels of $0,0.25,0.50,1.00 \%$ from one-day-old to 35 days of age. The $D A B$ samples were analyzed in triplicates. The productive traits were measured weekly and the biochemical indices at the end of the trial. Data was statistically analyzed by One-way ANOVA. It was found that slaughter body weight, body weight gain and average daily feed intake were increased in birds fed diets supplemented with DAB compared to the control ones. However, feed conversion ratio was not affected by any of the treatments. Broilers' serum enzymes activities and markers indicated that liver function as indicated by aspartate transaminase (AST) and alanine transaminase (ALT) and kidney's function which indicated by serum creatine and urea were not affected by DAB supplementation. Furthermore, protein, glucose and cholesterol levels in broiler's serum were in normal levels and not affected by treatments. No significant changes were observed in relative organ weights (spleen, bursa, liver, gizzard, proventriculus and heart) or intestine length of broilers at 35 days of age in response to DAB supplementation in their diets. It could be concluded that DAB supplementation to broiler diets from 1 to 35 days of age up to $1 \%$ had no negative impacts and might have had a positive effect on broiler performance at 35 days of age.

\section{INTRODUCTION}

Recently, the use of algae as a source of biofuels and feed for poultry has received great attention. The quire for energy has become a must, and alongside the reduction of fossil fuels has been so rapid that it could lead to an energy emergency in the near future. Production of energy using photosynthetic organisms such as microalgae may be a feasible answer to some of these problems (El Baz et al., 2016). The use of algae as a source of biofuels would be economically meaningful if defatted algal biomass (DAB) was reused. Since algal biomass is rich in proteins, carbohydrates, minerals and bioactive compounds it is ideal for feed applications (Population Reference Bureau, 2012). Therefore, it might be useful to be used as a source of protein feed for poultry.

The use of algae as a source of biofuels and feed for animals offers a double benefit since the use of algae as a source of fuel does not compete with agricultural crops and at the same time utilizes the remaining biomass of algae as feed for animals (Lum et al., 2013; Vidyashankar et al., 2013; El-Bahr et al., 2020).

The DAB can be used in many fields such as bio-ethanol production through anaerobic digestion (Chandra et al., 2014) or as a source of 
EI-Baz FK, Abdoon SM, El-Sayed DAA, Mostafa MA, Elsherif HMR, Safaa HM, Abdon AS
Application of Defatted Scenedesmus Obliquus Biomass for Broilers' Nutrition feed supplement for animals since algae contain a large amount of carbohydrates. The feed application of the defatted biomass would create a new source of animal feed to alleviate the current competition with human food supply. In addition the biofuel production of microalgae will be economically feasible.

There is no doubt that the nutritional value of algae has been studied many years ago by many researchers where, researches indicated that algae is a rich source of protein, sugars and antioxidants in addition to many dyes and has been used in many foods for humans and animals instead of synthetic materials (Yaakob et al., 2014). Recently, microalgae are used as a feed ingredient for livestock production and to improve meat quality (Madeira et al., 2017; Long et al., 2018; 2020; Pestana et al., 2020). On the same context, Park et al. (2018) indicated that Spirulina contains physiological active components. These components potentially work as antimicrobial, antioxidant, anti-inflammation and immune enhancer agents. It seems to be involved in metabolic actions related to growth performance in broiler chickens (Pestana et al., 2020). Moreover, different species of microalgae are successfully used in poultry diets such as Aurantiochy trium Chlorella, Dunaliella and Scenedesmus (Abdo et al., 2019; Kakhki et al., 2020). In addition, previous studies have shown that DAB can be used as feed for swine and poultry instead of corn and soybeans (Wu et al., 2018).

Therefore, the aim of this study was to investigate the possibility of supplementing defatted Scenedesmus obliquus biomass after extracting the oils from the biomass to broilers' diets from one-day-old to marketing age at 35 days of age on broilers' performance and physiological status, and evaluating the best level of supplementation.

\section{MATERIALS AND METHODS}

\section{Experimental Design}

This study was performed in accordance with the guidelines of the institutional Ethics of Animal Use in Research Committee (EAURC), Cairo University, Egypt. The experimental design is completely randomized with single effect of DAB supplementation levels in broilers' diets.

\section{Birds' diets and husbandry}

A total of 480 Arbor Acres Broiler chicks (mixed sex) at one-day old were obtained from a Cairo Poultry Company (10 $10^{\text {th }}$ of Ramadan city, Egypt). Chicks were divided randomly into 4 treatments (broiler basal diets supplemented (as percentage) with 0 (control),
0.25, 0.5 and 1 of defatted green alga Scenedesmus obliquus biomass).

At arrival in the farm, the birds were wing-banded and weighed. The chicks were housed under the same environmental conditions in battery cages. The birds were divided into 3 replicates each replicate consisting of 10 females and 10 males.

\section{Productive traits}

The BW (body weight) and feed consumption were recorded by replicate weekly and mortality was recorded daily. From these data BWG (body weight gained), average daily feed intake (ADFI) and feed conversion ratio (FCR) were calculated. The FCR was performed to evaluate the feed quality in the study and it was calculated as the ratio of weight gain over total feed intake during the experiment (Moreira et al., 2013).

\section{Serum biochemistry and Slaughter traits}

At 14,28 , and 35 days of age 6 chicks were chosen at random per group from the battery cages. All birds were weighted, slaughtered and eviscerated carcass heart, liver, gizzard, spleen and bursa were weighed. Consequently, relative weight to live BW $(g / 100 g$ of BW) were calculated.

Serum was separated by allowing the blood to stand for 2 to $4 \mathrm{~h}$ in an ice bath. Serum biochemical markers such as serum glutamate oxaloacetate transaminase which is called aspartate transaminase (SGOT=AST) and glutamate pyruvate transaminase which is called alanine transaminase (SGPT=ALT), cholesterol, glucose, albumin, total proteins, urea and creatinine were estimated using commercially available biochemical kits (Aspen Laboratories Pvt. Ltd, New Delhi, India) according to modified International Federation of Clinical Chemistry and Laboratory Medicine (IFCC) method.

\section{Extraction of lipid from chicken}

Mixed parts of the thigh and chest were cut into pieces and then mixed well by vortex. Mixture of methanol and chloroform in the proportion of 2:1, was added and mixed well, then water was added and mixed again, then chloroform was applied again and centrifugation was done to get two phases. The chloroform layer is separated and the alcohol is evaporated. After that the fat is converted to fatty acid methyl ester (FAME) by $5 \%$ methanolic $\mathrm{HCl}$ under reflux for $2 \mathrm{hrs}$. The samples were subjected to the GC analysis (Hewlett Packard HP 6890 series GC System Made in USA), each sample was analyzed in triplicate (Hulan et al., 1988). 
El-Baz FK, Abdoon SM, El-Sayed DAA, Mostafa MA, Elsherif HMR, Safaa HM, Abdon AS
Application of Defatted Scenedesmus Obliquus Biomass for Broilers' Nutrition

\section{Microalgae Cultivation}

The isolated microalgae species Scenedesmus obliquus was cultured on Bold's basal medium. The stock solutions were prepared from the chemicals Bold's Nutrient Composition: Urea, $0.3 \mathrm{~g} / \mathrm{L}, \mathrm{K}_{2} \mathrm{HPO}_{4}$, $0.075 \mathrm{~g} / \mathrm{L}, \mathrm{KHPO}_{4}, 0.175 \mathrm{~g} / \mathrm{L}, \mathrm{MgSO}_{4}\left(7 \mathrm{H}_{2} \mathrm{O}\right), 0.075 \mathrm{~g} / \mathrm{L}$, $\mathrm{NaCl}, 0.025 \mathrm{~g} / \mathrm{L}, \mathrm{CaCl}_{2}\left(2 \mathrm{H}_{2} \mathrm{O}\right), 0.025 \mathrm{~g} / \mathrm{L}, \mathrm{ZnSO}_{4}\left(7 \mathrm{H}_{2} \mathrm{O}\right)$, $8.8 \mathrm{mg} / \mathrm{L}, \mathrm{MnCl}_{2}\left(4 \mathrm{H}_{2} \mathrm{O}\right), 0.44 \mathrm{mg} / \mathrm{L}, \mathrm{MOO}_{3} 0.071 \mathrm{mg} / \mathrm{L}$, $\mathrm{CuSO}_{4}\left(5 \mathrm{H}_{2} \mathrm{O}\right), 1.57 \mathrm{mg} / \mathrm{L}, \mathrm{H}_{3} \mathrm{BO}_{3}, 11.42 \mathrm{mg} / \mathrm{L}$, EDTA, $50 \mathrm{mg} / \mathrm{L}, \mathrm{KOH}, 31 \mathrm{mg} / \mathrm{L}, \mathrm{Fe} \mathrm{SO}_{4}\left(7 \mathrm{H}_{2} \mathrm{O}\right), 4.98 \mathrm{mg} / \mathrm{L}$, $\mathrm{Co}\left(\mathrm{NO}_{3}\right)_{2} \cdot 6 \mathrm{H}_{2} \mathrm{O}, 0.49 \mathrm{mg} / \mathrm{L}, \mathrm{H}_{2} \mathrm{SO}_{4}, 1 \mu \mathrm{l} / \mathrm{L}$.

The culture temperature was $22 \pm 3^{\circ} \mathrm{C}$. Fluorescent light was used to supply constant light intensity for the culture $\approx 2500 \mathrm{~lx}$. The microalgae were grown in 5 Liters flasks, the culture was grown for three days then harvested and the whole biomass was transferred to a photo-bioreactor containing 4000 liters capacity. The cultures were supplied with air using an air pump to generate large, slow bubbles to mix the culture and increase the contact of the culture with air and the medium. The microalgae cells were harvested by settling, and then the settled biomass was subjected to centrifugation at $2000 \mathrm{rpm}$ for $10 \mathrm{~min}$. The collected biomass was dried using sun dryer.

\section{Oil Extraction}

The biomass of microalgae was dried in solar dryer and ground into homogenous fine powder. The dry cells were mixed with $n$-hexane and Isopropanol with the ratio of $3: 2(\mathrm{v} / \mathrm{v})$ as co solvent. The homogenate mixture was subjected to a magnetic stirrer at $30^{\circ} \mathrm{C}$ for $2 \mathrm{hr}$. Cell residue was removed by filtering. The filtrate material was transferred into a separating funnel and sufficient water was added to induce biphasic layering. After settling, the solvent mixture was partitioned into two distinct phases, top dark green hexane layer containing most of the extracted lipids and bottom light green layer containing most of the co-extracted non lipids. The hexane layer was collected in a pre-weighted flask and evaporated using a rotary evaporator (Halim et al., 2011; El Baz et al., 2016). The residual solvent in the defatted biomass was removed by drying at constant temperature $30^{\circ} \mathrm{C}$ until constant weight.

\section{Chemical analysis and functional proper- ties of defatted algal biomass}

The moisture content was determined by oven drying at a known quantity of algal biomass at $110^{\circ} \mathrm{C}$ to a constant weight. Total ash content was determined by muffle preheated to $600^{\circ} \mathrm{C}$. Samples were heated at this temperature overnight (AOAC, 2005). The protein content was estimated by quantifying nitrogen content using Kjeldahl apparatus according to (Chapman and Pratt, 1978). Total carbohydrates content was determined by the phenol sulphuric acid method (Dubois, 1956).

\section{Determination of Mineral Elements}

To $0.25 \mathrm{~g}$ ashes specimens was digested with $10 \mathrm{ml}$ of boiling nitric acid $\left(1 \mathrm{~N} \mathrm{HNO}_{3}\right)$ and heated to dryness. The residue was then dissolved in $10 \mathrm{ml} 0.1 \mathrm{~N} \mathrm{HNO}_{3}$ filtered and stored in polyethylene flasks for analysis as described by Lacerda et al. (1985).

\section{Statistical analysis}

The DAB samples were analyzed in triplicates for proximate composition. Haematology profile and serum biochemical indices were measured from 6 birds per each group. Results are expressed as mean \pm standard deviation. Data on weekly body weight, feed intake, relative organs' weights and biochemical traits were statistically analyzed using one-way ANOVA. Tukey-Kramer multiple comparison test was performed to analyze the significant differences among means. $p<0.05$ was considered significant. The statistical analyses were carried out using general linear model (GLM), SAS software (SAS, 2004).

\section{RESULTS AND DISCUSSION}

\section{Composition of defatted algal biomass}

Using $n$-hexane for algal biomass extraction resulted in a reduction in oil content (Table 1) up to $80 \%$ in the $D A B$. The total carbohydrate content was $16 \mathrm{~g} / 100 \mathrm{~g}$. In addition the DAB has $12.8 \%$ ash content. Referring to moisture content the $\mathrm{DAB}$ has $7.55 \%$ moisture content.

Table 1 - Proximate composition of defatted algal biomass.

\begin{tabular}{lc}
\hline Proximate components (\%) & $\mathrm{g} 100 \mathrm{~g}^{-1}$ biomass \\
\cline { 2 - 2 } & Defatted algal biomass \\
\hline Protein & $15.30 \pm 0.14$ \\
Carbohydrates & $16.00 \pm 0.04$ \\
Total ash & $12.80 \pm 0.60$ \\
Moisture & $07.55 \pm 0.50$ \\
& \\
Total lipid as oil content & $02.00 \pm 0.51$ \\
\hline
\end{tabular}

Values are average of triplicates and represented as mean \pm standard deviation.

\section{Fatty acids composition of Scenedesmus obliquus}

Table (2) showed that DAB of Scenedesmus obliquus contains palmitic acid (C: 16:0) with a high percentage $(30.2 \%)$, stearic acid (C: 18:0) with a percentage of 
El-Baz FK, Abdoon SM, El-Sayed DAA, Abdon AS Mostafa MA, Elsherif HMR, Safaa HM,

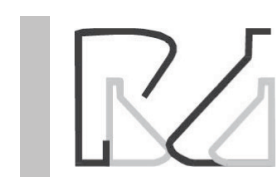

(24.2\%). Oliec and Linoleic acids (C: 18:1, C: 18:2) has the percentage $(11.8,26 \%)$, respectively. In addition, Linolenic and $\omega$-Linolenic were detected in smaller amounts.

Table $\mathbf{2}$ - Fatty acids profile of defatted green microalga Scenedesmuso bliquus.

\begin{tabular}{llc}
\hline Fatty acids & Common name & Defatted algal biomass (\%) \\
\hline C:14:0 & Myristic & 1.4 \\
C:16:0 & Palmitic & 30.2 \\
C:17:0 & Margaric acid & 1.3 \\
C:18:0 & Stearic acid & 24.2 \\
C:16:1 & Palmetolic & 2.1 \\
C:18:1 & Oleic & 11.8 \\
C:18:2 & Linoleic & 26.0 \\
C:18:3 & Linolenic & 0.9 \\
C:18:3 & w-Linolenic & 1.4 \\
\hline
\end{tabular}

\section{Mineral content of Scenedesmus obliquus DAB}

Elemental composition such as sodium, potassium, calcium, magnesium, Iron, zinc and copper in addition to ash content were measured in the DAB of Scenedesmus obliquus. Potassium was the highest among the elements followed by calcium (Table 3).

Table 3 - Mineral Composition of Scenedesmus obliquus biomass $(\mathrm{mg} / \mathrm{Kg})$.

\begin{tabular}{lc}
\hline Mineral & Defatted algal biomass \\
\hline Sodium & 1000 \\
Potassium & 6250 \\
Calcium & 6070 \\
Magnesium & 5550 \\
Iron & 1230 \\
Zinc & 100 \\
Copper & 50.5 \\
\hline
\end{tabular}

The DAB of microalgal species, after the biofuel production research, has only recently been used as supplementary in diets for poultry, swine, and cattle (Isaacs et al., 2011; Lum et al., 2012; Austic et al., 2013). Moreover, the study of Swiatkiewicz et al. (2016) proved that the use of DAB improved the performance of birds, health and the quality of meat and eggs.
Application of Defatted Scenedesmus Obliquus Biomass for Broilers' Nutrition

\section{Boilers' performance}

Dietary treatments increased body weight (BW), BW gain (BWG), and average daily feed intake (ADFI) of the birds fed diets supplemented with DAB compared to the control ones (Table 4). However, the feed conversion ratio (FCR) did not differ among the groups. These results are in agreement with El-Bahr et al. (2020) who indicated that the inclusion of microalgae in broiler diet up to 36 days of age enhanced growth performance. In the same context, these results are in consistence with the results obtained by Park et al. (2018) and Pestana et al. (2020) with Spirulina supplementation in broilers' diets. In addition, Long et al. (2020) reported that Forsythia suspensa extract improved Arbor Acre broilers' BWG and ADFI from 1 to 42 days of age in comparison with the control ones. On the other hand, Martinez et al. (2019) noted that broiler diets supplemented with up to $0.30 \%$ red algae powder from 1 to 32 days of age did not affect BW at 32 days of age and FCR but, feed intake was increased. However, Abdo et al. (2010) detected no significant effect of BW, and ADFI in broilers fed diets supplemented with $1 \%$ dried microalgal biomass harvested from high rate algal ponds. Moreover, Leng et al. (2014) showed that feeding with $7.5 \%$ defatted Staurosira spp has no adverse effect of feeding layers when used for partial replacement of soybean meal. However, feeding with $15 \%$ decreased egg performance, feed intake and FCR. Sodium chloride concentration and ash content may be the cause in such a decrease in performance. Although, Ekmay et al. (2015) demonstrated that using defatted Desmodesmus and Staurosira spp up to $25 \%$ in the diet could be used in laying hen diets as a source of well-digested dietary protein, without any negative effect on egg production.

\section{Serum biochemistry}

The toxicity of a test material can be determined by the biochemical study of the serum (Schilter et al.,

Table 4 - Effect of defatted algal biomass on the productivity of broiler chicks.

\begin{tabular}{|c|c|c|c|c|}
\hline Scenedesmus supplementation & Body Weight & Average Daily Body Weight Gain & Average Daily Feed Intake & Feed Conversion Ratio \\
\hline (g/100 g diet) & BW at 35 day $(\mathrm{g})$ & BWG $(\mathrm{g})$ & ADFI $(\mathrm{g})$ & FCR $(g: g)$ \\
\hline 0.00 & $1780^{\circ}$ & $49.65^{c}$ & $93.2^{c}$ & 1.88 \\
\hline 0.25 & $1834^{b}$ & $51.20^{\mathrm{b}}$ & $94.1^{c}$ & 1.84 \\
\hline 0.50 & $1837^{b}$ & $51.26^{b}$ & $95.8^{\mathrm{b}}$ & 1.87 \\
\hline 1.00 & $1929^{a}$ & $53.84^{\mathrm{a}}$ & $98.6^{a}$ & 1.83 \\
\hline $\operatorname{SEM}(n=6)^{1}$ & 20.6 & 0.533 & 0.48 & 0.065 \\
\hline Standard deviation & 50.5 & 1.306 & 1.16 & 0.148 \\
\hline$p$ value & 0.0005 & 0.0130 & 0.0201 & 0.1113 \\
\hline
\end{tabular}

${ }^{1}$ Standard error of the mean ( $n=6$ replicates of 10 birds per each).

$a, b, c$ Means with different superscript significantly differ at $p \leq 0.05$. 
2003). Table (5) showed the serum biochemical profile of broilers fed diets supplemented with DAB. Birds fed diets supplemented with DAB had no effects on liver functions as indicated by the levels of glutamate oxaloacetate transaminase (SGOT) and glutamate pyruvate transaminase (SGPT). Consequently, activities of serum enzymes in broilers were not affected by DAB supplementation in broilers' diets. The clinical studies of kidney function indicated by creatinine and urea levels in the serum were at the same level among the various groups. Total cholesterol which is the indicator of lipid metabolism was in the normal range and did not vary among the DAB fed and control groups. Moreover, total serum albumin levels were not changed also in DAB-fed groups compared with the control one. In general, the serum biochemical profile of broiler suggests the non-toxic nature of DAB at tested levels. In the same context, Austic et al. (2013) and Gatrell et al. (2014) reported no differences in plasma total cholesterol, triglycerides, NEFA, glucose, alkaline phosphatase and or alanine transaminase activity when broiler chicks fed diets containing 7.5\% defatted algal for 6 weeks in comparison with the control birds. However, it was found that the volume and wetness of excreta was increased compared with the control group when fed with diets containing DFA (Grau \& Klein 1957; Austic et al., 2013). In addition, Vidyashankar et al. (2014) found that liver and kidney functions were not affected when broiler was fed with DAB.

Table 5 - Effect of defatted algal biomass on broilers' serum biochemistry.

\begin{tabular}{lcccccccccc}
\hline $\begin{array}{l}\text { Scenedesmus } \\
\text { supplementation }\end{array}$ & AST & ALT & Creatine & Urea & T.protein & Albumin & Globulin & Glucose & Cholesterol \\
\hline$(\mathrm{g} / 100 \mathrm{~g}$ diet $)$ & $(\mathrm{U} / \mathrm{dL})$ & $(\mathrm{U} / \mathrm{dL})$ & $(\mathrm{mg} / \mathrm{dL})$ & $\mathrm{mg} / \mathrm{dL}$ & $(\mathrm{g} / \mathrm{dL})$ & $(\mathrm{g} / \mathrm{dL})$ & $(\mathrm{g} / \mathrm{dL})$ & $(\mathrm{mg} / \mathrm{dL})$ & $(\mathrm{mg} / \mathrm{dL})$ \\
0.00 & 269.3 & 19.6 & 0.48 & 5.7 & 3.60 & 1.91 & 1.69 & 234.8 & 102.6 \\
0.25 & 251.0 & 20.4 & 0.48 & 6.5 & 3.57 & 1.82 & 1.75 & 250.3 & 114.2 \\
0.50 & 250.8 & 21.2 & 0.53 & 6.3 & 3.39 & 1.87 & 1.53 & 244.2 & 115.5 \\
1.00 & 241.9 & 18.9 & 0.44 & 5.9 & 3.62 & 2.04 & 1.58 & 242.0 & 128.6 \\
SEM $(\mathrm{n}=6)$ & 6.82 & 1.12 & 0.041 & 0.26 & 0.243 & 0.139 & 0.149 & 8.99 & 11.78 \\
Standard deviation & 16.71 & 2.74 & 0.100 & 0.64 & 0.595 & 0.341 & 0.365 & 22.02 & 28.86 \\
$p$ value & 0.0530 & 0.4851 & 0.4093 & 0.1430 & 0.9016 & 0.6801 & 0.6982 & 0.6817 & 0.4668 \\
\hline
\end{tabular}

${ }^{1}$ standard error of the mean ( $n=6$ replicates of 10 birds per each).

No significant differences were detected for all traits at $p \leq 0.05$.

Feeding broiler for 5 weeks with DAB showed no variations on the body weight among the control and test groups (Table 6). Results indicated no difference between the control and DAB supplementation groups. The $D A B$ proved to be non-toxic during repeated feeding. No significant changes were observed in relative organ weights such as spleen, bursa, liver and gizzard. Vidyashankar et al. (2014) were in agreement with the results obtained, where they stated that the relative organs weights indicated no unwanted effects on birds upon DAB feeding. In the same context, Martinez et al. (2019) reported that broiler diets supplemented with up to $0.30 \%$ algae powder did not affect the relative weights of spleen, bursa of fabricius, liver, gizzard and heart.

It has been reported that protein metabolites in blood and the bursa and spleen relative weights as immune organs, indicate the immunity status of the birds (Safaa et al., 2011; Safaa, 2013). In this respect, the results of serum globulin, total protein and albumin (Table 5) and spleen and bursa relative weights (table 6) might indicate that no impaired impact of $D A B$ supplementation up to $1 \%$ to broilers' diets affects broilers' immunity.

Table 6 - Effect of defatted algal biomass on Broilers' Slaughter traits.

\begin{tabular}{lccccccccc}
\hline $\begin{array}{l}\text { Scenedesmus } \\
\text { supplementation }\end{array}$ & $\begin{array}{c}\text { Body } \\
\text { weight }\end{array}$ & $\begin{array}{c}\text { Slaughter } \\
\text { weight }\end{array}$ & Spleen & Bursa & Liver & Gizzard & $\begin{array}{c}\text { Intestine } \\
\text { Length }\end{array}$ & Proventriculus & Heart \\
\hline$(\mathrm{g} / 100 \mathrm{~g}$ diet $)$ & $\mathrm{BW}(\mathrm{g})$ & $(\mathrm{g} / 100 \mathrm{~g} \mathrm{BW})$ & $(\mathrm{mg} / 100 \mathrm{~g} \mathrm{BW})$ & $(\mathrm{mg} / 100 \mathrm{~g} \mathrm{BW})$ & $(\mathrm{g} / 100 \mathrm{~g} \mathrm{BW})$ & $(\mathrm{g} / 100 \mathrm{~g} \mathrm{BW})$ & $(\mathrm{cm} / 100 \mathrm{~g} \mathrm{BW})$ & $(\mathrm{g} / 100 \mathrm{~g} \mathrm{BW})$ & $(\mathrm{g} / 100 \mathrm{~g} \mathrm{BW})$ \\
0.00 & $1645^{\mathrm{c}}$ & $91.3^{\mathrm{b}}$ & 117.0 & 95.7 & 2.04 & 1.88 & 11.3 & 0.52 & 0.51 \\
0.25 & $1773^{\mathrm{b}}$ & $93.5^{\mathrm{a}}$ & 123.6 & 160.2 & 2.18 & 1.80 & 9.6 & 0.44 & 0.52 \\
0.50 & $1809^{\mathrm{b}}$ & $93.1^{\mathrm{a}}$ & 135.2 & 135.4 & 1.89 & 1.80 & 8.2 & 0.50 & 0.45 \\
1.00 & $1915^{\mathrm{a}}$ & $93.8^{\mathrm{a}}$ & 138.8 & 172.0 & 2.30 & 1.62 & 9.2 & 0.43 & 0.53 \\
SEM (n=6) & 18.7 & 0.48 & 16.72 & 17.82 & 0.246 & 0.129 & 1.47 & 0.045 & 0.049 \\
Standard deviation & 45.8 & 1.18 & 40.96 & 43.65 & 0.603 & 0.316 & 3.60 & 0.110 & 0.120 \\
p value & 0.0162 & 0.0188 & 0.0834 & 0.0991 & 0.5874 & 0.7641 & 0.6333 & 0.4824 & 0.6563 \\
\hline
\end{tabular}

'Standard error of the mean ( $n=6$ replicates of 10 birds per each).

$a, b, c$ Means with different superscript significantly differ at $p \leq 0.05$. 


\section{CONCLUSION}

Implications of DAB generating value-added in poultry production were proved to be applicable in broiler production. The use of algae in poultry feed will not only provide a safe solution for human and animal nutrition, but will also facilitate the cost-effective of biofuel production and reduces greenhouse gas production of agriculture. In addition, it has a positive impact on broiler productivity at market age (35 days of age).

\section{ACKNOWLEDGEMENT}

This work was supported and funded by the project entitled" Biodiesel production from algae as a renewable energy source". Funding organization: Research Development and Innovation program (RDI), Funding Program: EU-Egypt Innovation Fund, 20142016 .

\section{COMPETING INTERESTS}

"The authors declare that they have no competing interests."

\section{REFERENCES}

Abdo SM, Amer SA, Ahmed HM, Mahmoud RH, Salama AA, Kutkat MA. Microalgae biomass application in commercial broilers nutrition and their efficacy against challenge with epidemic Newcastle disease virus in Egypt. Journal of World's Poultry Research 2019;9(2):98-108.

AOAC. Official methods of analysis of AOAC International. $18^{\text {th }}$ ed. Gaithersburg; 2005.

Austic RE, Mustafa A, Jung B, Gatrell S, Lei X G. Potential and limitation of a new defatted diatom microalgal biomass in replacing soybean meal and corn in diets for broiler chickens. Journal of Agricultural and Food Chemistry 2013; 61:7341-7348.

Chandra TS, Suvidha G, Mukherji S, Chauhan VS, Vidyashankar $S$, Krishnamurthi $K$, et al. Statistical optimization of thermal pretreatment conditions for enhanced biomethane production from defatted algal biomass. Bioresource Technology 2014;162:157-165.

Chapman HD, Pratt, PF. Methods of analysis for soils, plants and waters. La Jolla: University of California Division of Agriculture and Natural Resources; 1978.

Dubois M, Gilles KA, Hamilton JK, Rebers PA, Smith F. Colorimetric method for the determination of sugars and related substances. Analytical Chemistry 1956;28:350-356

Ekmay RD, Chou K, Magnuon A, Lei X. Continual feeding of two typesofmicroalgal biomass affected protein digestion and metabolism in laying hens. Journal of Animal Science 2015;93:287-297.

El-Bahr S, Shousha S, Shehab A, Khattab W, Ahmed-Farid O, Sabike I, et al. Effect of dietary microalgae on growth performance, profiles of amino and fatty acids, antioxidant status, and meat quality of broiler chickens. Animals 2010;10(5):761.
El-Baz FK, Gad MS, Abdo SM, Abed KA, Matter Al. Performance and Exhaust emissions of a diesel engine burning algal biodiesel blends. International Journal of Mechanical \& Mechatronics Engineering IJMME-IJENS 2016;16(3):150-157.

Gatrell S, Lum K, Kim J, Lei XG. Nonruminant Nutrition Symposium: Potential of defatted microalgae from the biofuel industry as an ingredient to replace corn and soybean meal in swine and poultry diets. Journal of Animal Science 2014;92(4):1306-1314.

Grau CR, Klein NW. Sewage-grown algae as a feed stuff for chicks. Poultry Science 1957;36:1046-1051.

Halim R, Gladman B, Danquah MK, Webley, PA. Oil extraction from microalga for biodiesel production. Bioresource Technology 2011;102:178-185.

Hulan HW, Proudfoot FG, Ackman RG, Ratnayake WMN. Omega-3 fatty acid levels and performance of broiler chickens fed redfish meal or redfish oil. Canadian Journal of Animal Science 1988;68(2): 533-547.

Isaacs R, Roneker KR, Huntley M, Lei XG. A partial replacement of soybean meal by whole or defatted algal meal in diet for weanling pigs does not affect their plasma biochemical indicators [abstract]. Journal of Animal Science 2011;89:(Suppl 1):723.

Kakhki RAM, Price KR, Moats J, Bedecarrats G, Karrow NA, Kiarie EG. Impact of feeding microalgae (Aurantiochytrium limacinum) andco-extruded mixture of full-fatflaxseed as sources of n-3 fattyacids to ISA brown and Shaver white breeders and progeny onpullet skeletal attributes at hatch through to 18 weeks of age. Poultry Science 2020;99:2087-2099.

Lacerda LD, Rezende CE, José DM, Wasserman JC, Francisco MCF, Martins JC. Mineral concentrations in leaves of mangrove trees. Biotropica. $1985 ; 17: 260-262$.

Leng X, Hsu KN, Austic RE, Lei XG. Effect of dietary defatted diatom biomass on egg production and quality of laying hens. Journal of Animal Science and Biotechnology 2014;6:1-7.

Long SF, Kang S, Wang QQ, Xu YT, Pan L, Hu JX, et al. Dietary supplementation with DHA-rich microalgae improves performance, serum composition, carcass trait, antioxidant status, and fatty acid profile of broilers. Poultry Science 2018;97:1881-1890

Long SF, He TF, Wu D, Yang M, Piao XS. Forsythia suspensa extract enhances performance via the improvement of nutrient digestibility, antioxidant status, anti-inflammatory function and gut morphology in broilers. Poultry Science 2020;99(9):4217-4226

Lum K K, Roneker K R, Lei X G. Effects of various replacements of corn and soy by defatted microalgal meal on growth performance and biochemical status of weanling pigs [abstract]. Journal Animal Science 2012;90(3):701

Lum KK, Kim J, Lei XG. Dual potential of microalgae as asustainable biofuel feedstock and animal feed. Journal of Animal Science Biotechnology 2013:4:53.

Madeira MS, Cardoso C, Lopes PA, Coelho D, Afonso C, Bandarra NM, et al. Microalgae as feed ingredients for livestock production and meat quality: A review. Livestock Science 2017;205:111-121.

Martínez Y, Ayala L, Hurtado C, Más D, Rodríguez R. Effects of Dietary supplementation with red algae powder (chondrus crispus) on growth performance, carcass traits, lymphoid organ weights and intestinal $\mathrm{pH}$ in broilers. Brazilian Journal of Poultry Science 2019;21(4):1-8.

Moreira L, Behling M, Rodrigues BS, Costa RS, Soares AS. Spirulina as a protein source in the nutritional recovery of Wistar rats. Brazilian Archives of Biology and Technology 2013;56:447-456.

Park JH, Lee SI, Kim IH. Effect of dietary Spirulina (Arthrospira) platensis on the growth performance, antioxidant enzyme activity, nutrient digestibility, cecal microflora, excreta noxious gas emission, and breast meat quality of broiler chickens. Poultry Science 2018:97:2451-2459. 
El-Baz FK, Abdoon SM, El-Sayed DAA, Mostafa MA, Elsherif HMR, Safaa HM, Abdon AS

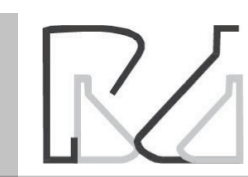

Application of Defatted Scenedesmus Obliquus Biomass for Broilers' Nutrition
Pestana JM, Puerta B, Santos H, Madeira MS, Alfaia CM, Lopes PA, et al. Impact of dietary incorporation of Spirulina (Arthrospira platensis) and exogenous enzymes on broiler performance, carcass traits, and meat quality. Poultry Science 2020;99:2519-2532.

Population Reference Bureau. World population data sheet. 2012. Available from: http://www.prb.org/pdf12/2012-population-data-sheet_eng. pdf.

Safaa HM. Influence of dietary enzymes prepared at ensiling (Zado®) from hatch to 42 days of age on productivity, slaughter traits and blood constituents in broiler chickens. International Journal of Poultry Science 2013;12 (9):529-537.

Safaa HM, El-Sayed DAA, Abdou AM, Shalash SMM, Riad SA. Influence of vaccination with different Avian Influenza vaccines at one or seven days-old on productivity, blood biochemical and immune response of broiler chicks. Egyptian Poultry Science Journal 2011;31:825-843.

SAS. Statistical analysis system. $7^{\text {th }}$ ed. Cary: SAS Institute; 2004.

Schilter B, Andersson C, Anton R, Constable A, Kleiner J, O'Brien J, et al. Guidance for the safety assessment of botanicals and botanical preparations for use in food and food supplements. Food and Chemical Toxicology 2003;41(12):1625-1649.
Światkiewicz S, Arczewska A, Jozefiak D. Application of microalgae biomass in poultry nutrition. World's Poultry Science Journal 2016;71(4):663672

Vidyashankar S, Deviprasad K, ChauhanVS, Ravishankar GA, Sarada R. Selection and evaluation of $\mathrm{CO} 2$ tolerant culture indigenous microalga Scenedesmus dimorphus for unsaturated fatty acid rich lipid production under different conditions. Bioresource Technology 2013;144:28-37.

Vidyashankar S, Venugopal KS, Muthukumar SP, Sarada R. Characterization of defatted Scenedes musdimorphus algal biomass as animal feed. Journal of Applied Phycology 2014;27:1871-1879.

Wu C, Yang Z, Song C, Liang C, Li H, Chen W, et al. Effect of dietary yeast nucleotides supplementation on intestinal barrier function, intestinal microbiota, and humoral immunity in specific pathogen-free chickens. Poultry Science 2018;97:3837-3846.

Yaakob Z, Ali E, Zainal A, Mohamad M, Takriff MS. An overview: biomolecules from microalgae for animal feed and aquaculture. Journal of Biological Research-Thessaloniki 2014;21(1):6. 
